Historic, Archive Document

Do not assume content reflects current scientific knowledge, policies, or practices. 



A99.9 Whatho

\title{
Management of Ponderosa Pine in Even-Aged Stands in the Southwest
}

\author{
Robert R. Alexander and \\ Carleton B. Edminster
}

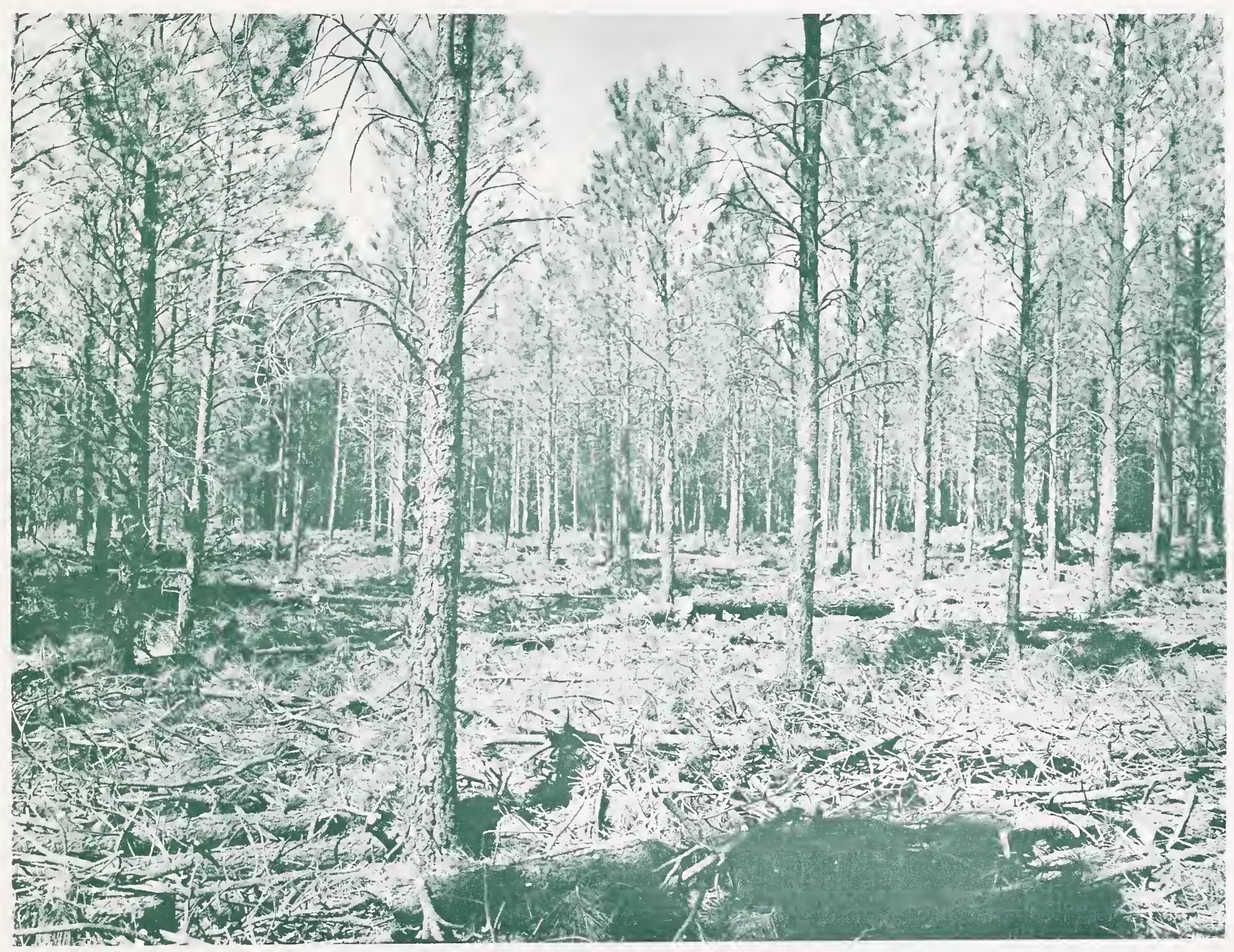

Research Paper RM-225

Rocky Mountain Forest and

Range Experiment Station

Forest Service

U.S. Department of Agriculture 


\section{0}

\section{Abstract}

Potential production of ponderosa pine in the Southwest is simulated for various combinations of stand density, site index, age, and thinning schedule. Such estimates are needed to project future development of stands managed in different ways. //

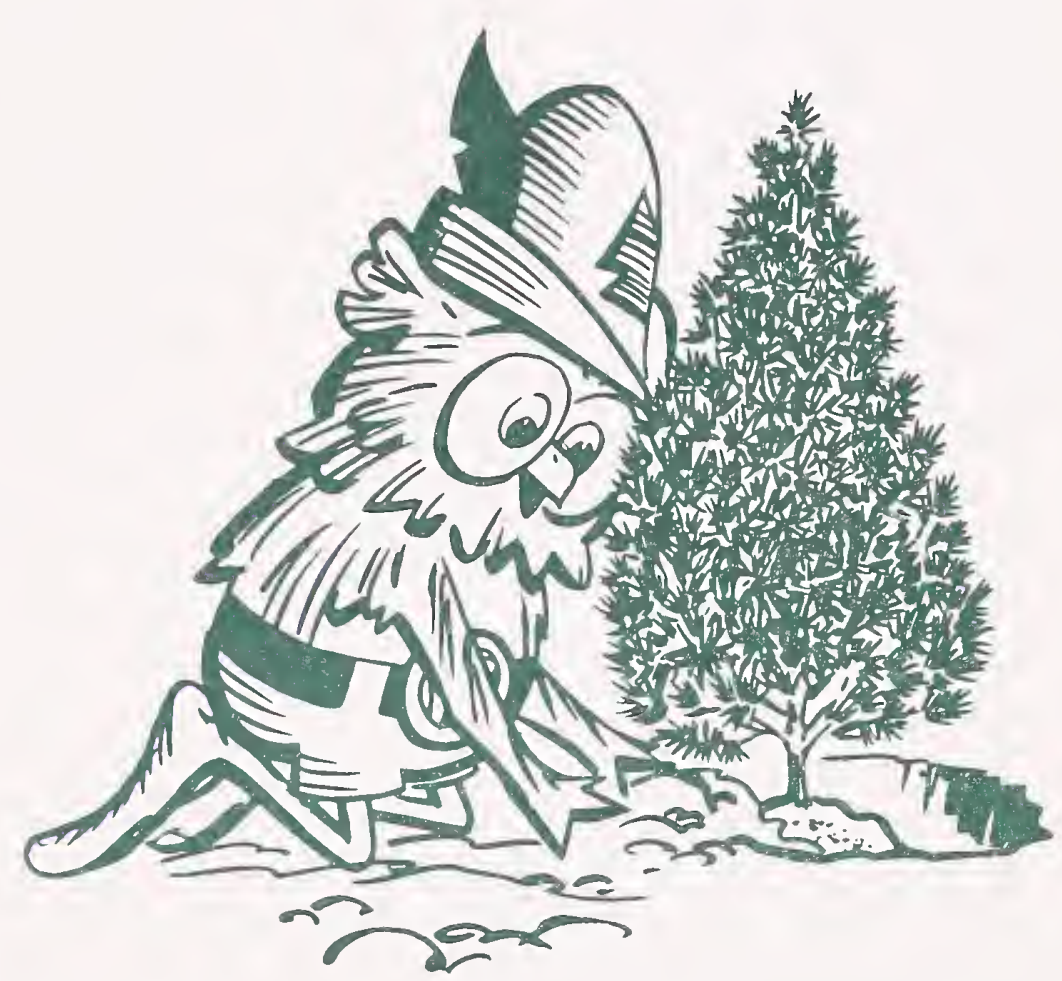

Plant a tree! Mark the 75th birthday of the Forest Service by giving a living gift to future generations. 


\title{
$2+5$ \\ Management of Ponderosa Pine in Even-Aged Stands in the Southwest .
}

\author{
Robert R. Alexander, Chief Silviculturist \\ and \\ Carleton B. Edminster, Mensurationist \\ Rocky Mountain Forest and Range Experiment Station'
}




\section{Contents}

Page

Silviculture of Southwestern Ponderosa Pine ............................ 1

Establishment of Regeneration . .................................. 1

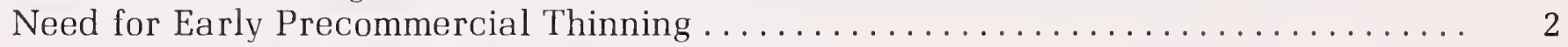

Estimates of Growth Under Intensive Management . . . . . . . . . . . . . . . . . 2

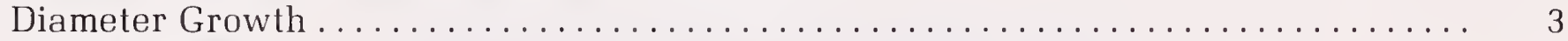

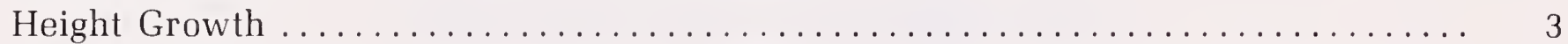

Basal Area Growth ......................................... 3

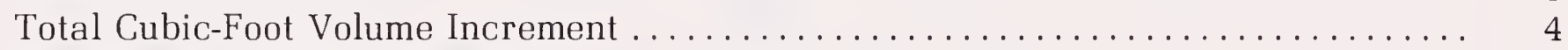

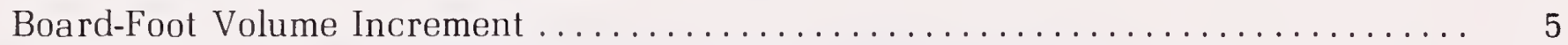

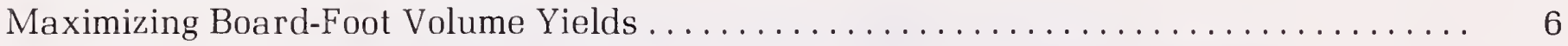

Tradeoffs to Increase Values of Other Resources . . . . . . . . . . . . . . . . 8

Management Gaution ........................................ 9

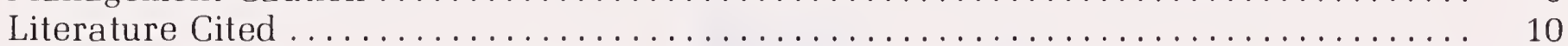

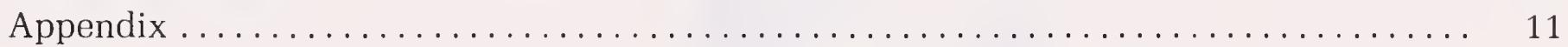




\title{
Management of Ponderosa Pine in Even-Aged Stands in the Southwest
}

\author{
Robert R. Alexander and Carleton B. Edminster
}

\section{Silviculture of Southwestern Ponderosa Pine}

Southwestern ponderosa pine ${ }^{2}$ (Pinus ponderosa Laws) cover type occupies the largest area of commercial forest land in Arizona and New Mexico (Choate 1966, Spencer 1966). It is less extensive in southwestern Colorado and southern Utah (Choate 1965. Miller and Choate 1964). Ponderosa pine forests in the Southwest occur between 6,000 and 8,500 feet elevation, but reach maximum development between 7,000 and 7,800 feet, where they are the climax forests (Schubert 1974).

Southwestern ponderosa pine forests were first cut during the Gold Rush of the mid-1800's. Commercial cutting began with construction of the transcontinental railroad during the late 1800 's. Since then, ponderosa pine forests have provided a variety of wood products, forage for livestock. and habitat for a variety of wildlife. Today other uses are becoming important.

How these forests are managed affects all resources and uses. For example, if timber production is the primary objective, higher growing stock levels (GSL) should be maintained, but forage production and water yields can be substantially increased only at lower GSL's. Low to medium GSL's are generally considered necessary to improve developed recreational opportunities and enhance foreground esthetics. Wildlife habitat varies from uncut to open forests. Improvement of middleground and background esthetics generally requires a combination of open, low stocking and high stocking levels that provide contrasts.

Although land managers must increasingly direct their practices toward multiple uses, these practices must be based on sound silvicultural principles of the forest type involved. Land managers must understand the tradeoffs between the timber resource and other physical, social, and economic considerations.

In the past, southwestern ponderosa pine has been under extensive management. Harvesting practices have generally been limited to "loggers selection" or

\footnotetext{
${ }^{2}$ Southwestern ponderosa pine as described here does not include the Front Range of Colorado and Wyoming.

${ }^{3}$ Growing stock level (GSL) is defined as the residual square feet of basal area when average stand diameter is 10 inches d.b.h. or more. Basal area retained in a stand with an average diameter of less than 10 inches is less than the designated level (Myers 1971, Edminster 1978). Tables A-1, A-2, and A-3 in the appendix give the basal area, number of trees, and square spacing in stands with average diameters after thinning of 2 to 10 inches, for GSL levels 40 to 160 .
}

sanitation salvage and improvement selection cutting that removed trees in a series of cuts on an individual or group basis. Cutover areas were allowed to restock naturally regardless of the time required or the stocking achieved. Today, management intensity has increased, and managers are concerned with (1) prompt restocking of cutover areas with a new stand, (2) increasing the growth rate of the new stand by control of stand density, and (3) improving quantity and quality of yields by periodic thinning to maintain stocking control and growth rates and reduce mortality.

In old growth stands, average annual net increment varies from 25 to $90 \mathrm{fbm}$ per acre because of understocking or overstocking and high mortality associated with old-growth timber (Pearson 1950). Under intensive even-aged management, annual net growth can be increased to 100 to $300 \mathrm{fbm}$ per acre (Edminster 1978).

Stand density control offers the greatest opportunity for increasing wood production by increasing growth and reducing mortality, but harvested stands must be replaced promptly to reduce time required to reach maximum yields. Ponderosa pine regeneration in the Southwest has been notoriously slow, and some areas have remained unstocked or poorly stocked for 50 years or longer. Periods of 10 to 30 years are more common, but they still are not compatible with rotations of 80 to 120 years. Low stumpage values have also hindered intensive management. Improving stumpage values and better understanding of natural and/or artificial regeneration allows forest managers to do the cultural work necessary to increase timber production.

\section{Establishment of Regeneration}

Southwestern ponderosa pine forests can be maintained as productive forests under an even-aged management system. A two-cut shelterwood method is most appropriate for converting even-aged, old-growth stands to managed even-aged stands (Schubert 1973). Uneven-aged, old-growth stands require at least a three-cut shelterwood that may incorporate features of sanitation-salvage and improvement selection methods for conversion to managed, even-aged stands. An uneven-aged management system which includes individual tree selection and group selection cutting methods is also appropriate for use in ponderosa pine stands. They are not discussed in this paper because suitable growth and yield prediction tools are not available for managed, uneven-aged stands. 
Natural regeneration of ponderosa pine will be slow to establish and poorly distributed under any cutting method if any of the following requirements are not met (Schubert 1974):

1. A large supply of viable seed.

2. A well prepared seedbed.

3. A site free of competing vegetation.

4. A low population of seed-eating animals.

5. Sufficient soil moisture.

6. Protection from trampling and browsing and certain insects.

If cutover stands remain unstocked or poorly stocked more than 5 years after final harvest, the manager must take action under the regulations of the National Forest Management Act of 1976 to artificially regenerate the areas. Schubert (1974) summarized guidelines for planting and direct seeding of southwestern ponderosa pine.

Schubert (1974) recommends planting at least 680 trees per acre. This should provide a stocking of 340 trees per acre when average stand diameter reaches 5 inches d.b.h., which is GSL 80. However, if ponderosa pine is to be managed at higher GSL's, a minimum of 1,000 to 1,200 trees per acre should be planted.

\section{Need for Early Precommercial Thinning}

Establishing a new stand is only the beginning. Trees must have room to grow to reach merchantable size in a reasonable amount of time. Where ponderosa pine has regenerated well naturally in the Southwest, reproduction is often overly dense-the 1919 seedling crop is a notable example. At Taylor Woods, on the Fort Valley Experimental Forest in Arizona, stands with an average of 5,800 stems per acre reached an average stand diameter of 2.6 inches in 43 years, and more than one-third of a 120 -year rotation has passed without any usable wood production (Schubert 1971). For acceptable growth rates, precommercial thinning is needed to reduce stand density to 1.000 to 1,200 stems per acre before age 10 years.

When adequate numbers of well distributed seedlings become established within 5 years after the seedcut of a shelterwood method, the removal cut should be made promptly to avoid suppression. In stands infested with dwarf mistletoe, the longer the overwood remains in place, the greater is the probability of transmitting the parasite to the new stand.

\section{Estimates of Growth Under Intensive Management}

Intensive management of southwestern ponderosa pine forests provides many opportunities for increasing usable wood production, but estimates of future stand development under various management regimes are needed.
Information available on the growth of ponderosa pine from sapling stage to final harvest under evenaged management with a shelterwood cut is provided by field and computer simulation procedures developed by Myers (1971) and Myers et al. (1976) and refined by Edminster (1978). The procedures were developed from field data on past growth as related to stand density, age, and site quality.

The modeling concept used in these programs holds that the whole stand is the primary model unit, characterized by average values. The equations upon which the growth and yield simulations are based are given in Myers et al. (1976). The programs project stand development by consecutive, 10 -year periods and include relationships to project average stand diameter, average dominant and codominant height, and number of trees per acre. Average diameter at the end of a projection period is a function of average diameter at the beginning of the period, site index, and basal area per acre. Periodic average dominant and codominant height growth at managed stand densities is a function of age and site index. Periodic mortality is a function of average diameter and basal area per acre. Adjustments are made to the growth and mortality functions to account for the effects of dwarf mistletoe infestation. Stand volume equations are used to compute total cubic feet per acre; factors are computed to convert this to merchantable cubic feet and board feet. Prediction equations are included to estimate the effects of differing intensities of thinning from above and below on average diameter, average dominant and codominant height, trees retained per acre, and average dwarf mistletoe rating (Hawksworth 1977).

Yield simulations discussed in the following paragraphs were made to the same hypothetical initial stand conditions for all growth parameters:

1. Average total age at first thinning is 30 years.

2. Average stand diameter is 4.5 inches d.b.h. ${ }^{4}$

3. Stand density is 1,000 trees per acre.

4. Site index is $50,60,70,80$, and 90 at base age 100 years (Meyer 1961).

5. Dwarf mistletoe rating is 0 .

6. Projections were made for 50 years (stand age 80 years) and 90 years (stand age 120 years).

7. Thinnings from below were made every 20 and 30 years to GSL's of $40,60,80,100,120,140$, and 160. Initial and subsequent entries were made to the same GSL.

8. A two-cut shelterwood option was used. The seed cut was made 20 years before final cut and retained $50 \%$ of the subsequent GSL.

9. Minimum size for inclusion in board-foot volume determination was 10 inches d.b.h. to a variable top diameter. Stand volumes were determined from tables prepared by Myers (1963).

10. All entries were made as scheduled, even though all thinnings could be precommercial.

\footnotetext{
${ }^{4}$ Average stand diameter is the diameter of the tree of average
} basal area; it is not the average of all the tree diameters. 


\section{Diameter Growth}

Periodic mean annual diameter growth of southwestern ponderosa pine is related to stand density and site quality, but is affected little by the cutting cycles tested. Cutting cycles do influence average stand diameter, however, because thinning from below increases average diameter at each entry. Actual basal area in a stand with an average diameter of less than 10 inches d.b.h. continues to increase, because periodic thinning does not reduce basal area to a fixed (GSL) amount until an average stand diameter of 10 inches d.b.h. is reached. Consequently, the rate of diameter growth for a given GSL is not constant over time and is essentially a negative exponential function of basal area per acre in the program. In contrast, periodic diameter growth is a linear function of site index, so that differences in diameter growth resulting from site quality are constant throughout the range of GSL's and rotations examined.

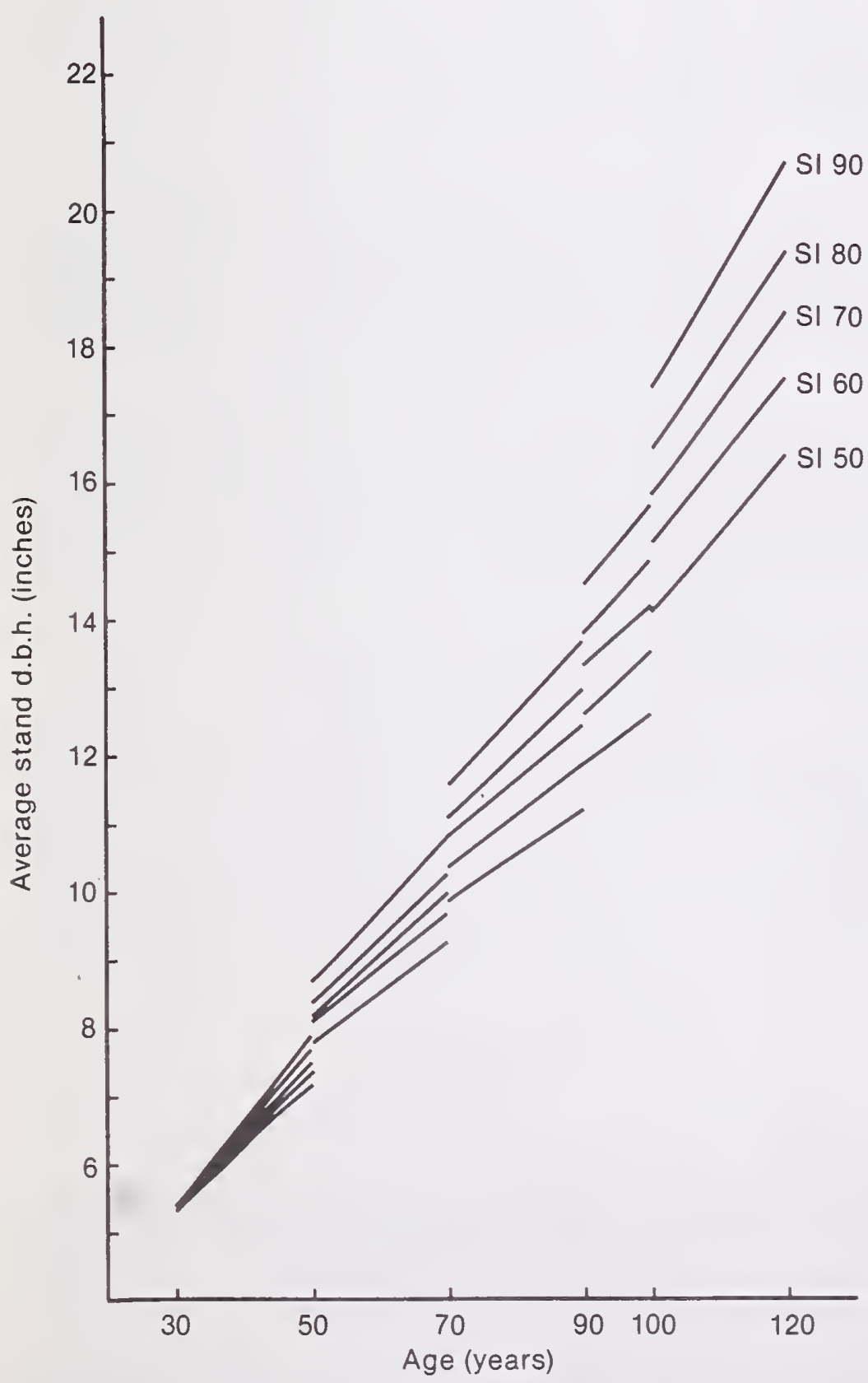

Figure 1.-Estimated average stand diameter of southwestern ponderosa pine in relation to age for different site classes at GSL 100 , with a 20 -year thinning interval and 120 -year rotation.

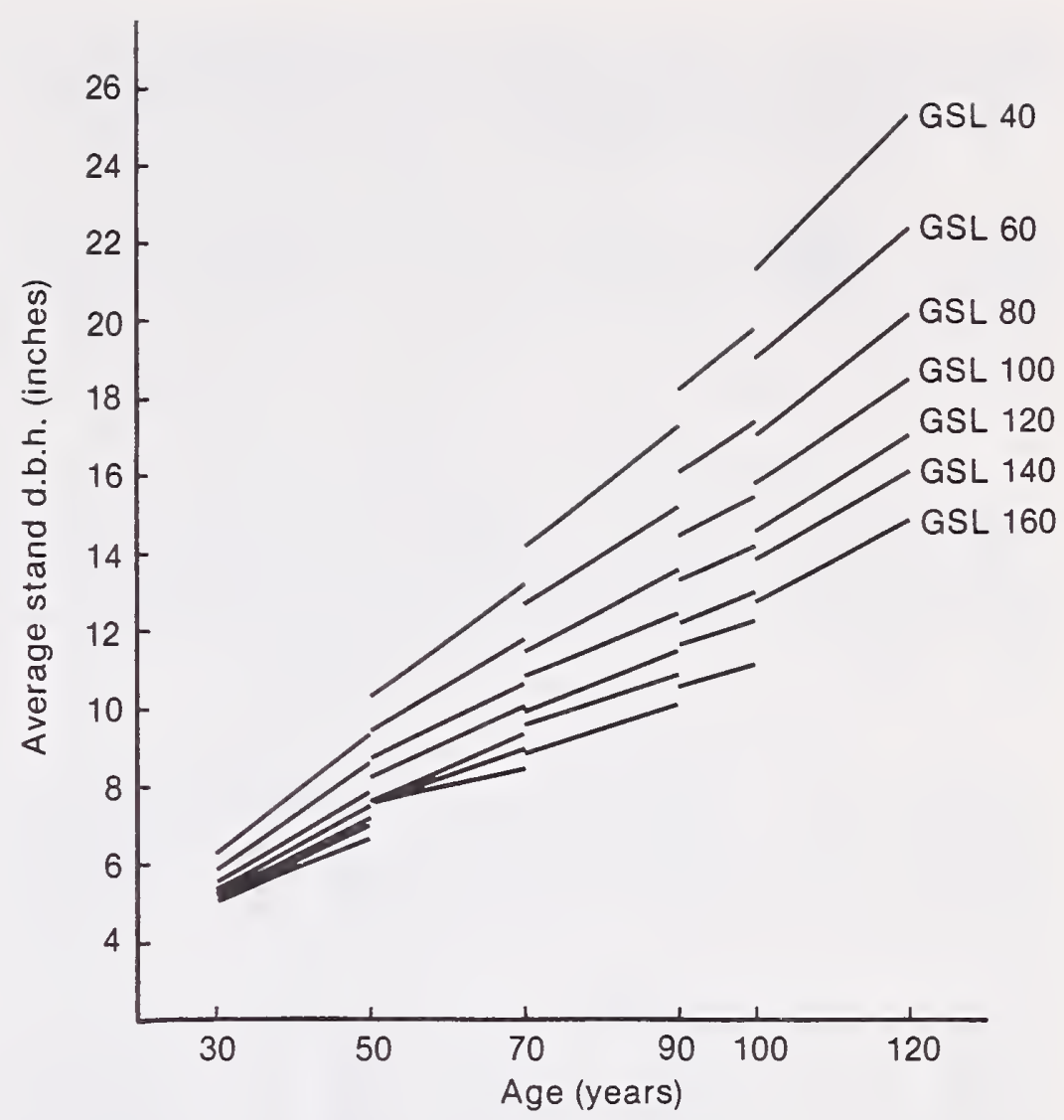

Figure 2.-Estimated average stand diameter of southwestern ponderosa pine in relation to age and GSL on site index 70 lands with a 20 -year thinning interval and 120-year rotation.

Growth rates and changes in diameter resulting from thinning frequency were examined to determine average size of trees relative to rotation age. For example, at GSL 100 with a 20-year cutting cycle, trees reach average stand diameters of 12.3 to 14.4 inches d.b.h. after 80 years; and 16.4 to 20.7 inches d.b.h. after 120 years for the range of sites tested (fig. 1). On an average site (index 70 ), with a 20 -year cutting cycle, mean stand diameters reached 10 inches d.b.h. at 50 to 88 years of age for the range of GSL's 40 to 160 (fig. 2).

\section{Height Growth}

Periodic mean annual height growth of ponderosa pine increases with site index and decreases with age, but is unaffected by GSL's or cutting cycles. However, because fewer and, therefore, taller trees are left after each thinning from below, the mean height of the dominant and codominant trees is increased slightly at each entry. The increase is positively correlated with thinning frequency and negatively correlated with GSL.

\section{Basal Area Growth}

Periodic mean annual basal area increment is related to growing stock level, site quality, frequency of thinning, and rotation age. Because actual basal area continues to increase in a stand until average stand diameter reaches 10 inches d.b.h. and thinning reduces basal area to a fixed amount (GSL), the rate of basal area growth for a given GSL is not constant over 
Table 1. - Estimated total cubic foot volume production per acre of southwestern ponderosa pine in relation to growing stock level, rotation age, cutting cycle, and site index

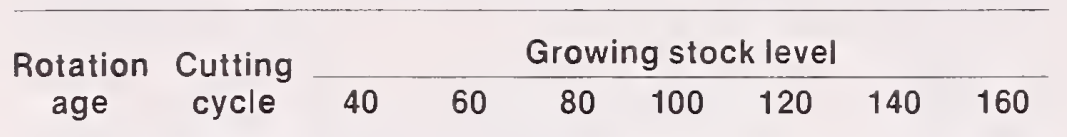

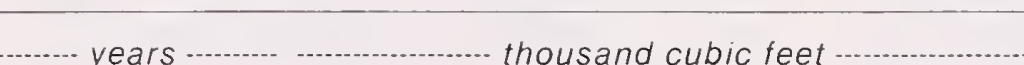

Site index 50

$\begin{array}{rllllllll}80 & 20 & 2.13 & 2.43 & 2.68 & 2.88 & 3.00 & 3.06 & 3.13 \\ 120 & & 3.04 & 3.67 & 4.08 & 4.39 & 4.60 & 4.74 & 4.82 \\ 80 & 30 & 2.20 & 2.53 & 2.72 & 2.87 & 3.00 & 3.10 & 3.13 \\ 120 & & 3.14 & 3.76 & 4.21 & 4.45 & 4.60 & 4.67 & 4.69\end{array}$

Site index 60

$\begin{array}{rllllllll}80 & 20 & 2.53 & 2.93 & 3.27 & 3.54 & 3.74 & 3.86 & 3.94 \\ 120 & & 3.66 & 4.44 & 5.02 & 5.44 & 5.82 & 6.00 & 6.08 \\ 80 & 30 & 2.62 & 3.03 & 3.36 & 3.57 & 3.73 & 3.89 & 3.99 \\ 120 & & 3.76 & 4.58 & 5.23 & 5.64 & 5.94 & 6.12 & 6.30 \\ & & & & & & & & \\ & & & & & & & \\ 80 & 20 & 3.00 & 3.52 & 3.91 & 4.19 & 4.49 & 4.70 & 4.80 \\ 120 & & 4.30 & 5.28 & 6.05 & 6.66 & 7.20 & 7.56 & 7.68 \\ 80 & 30 & 3.14 & 3.61 & 3.99 & 4.30 & 4.56 & 4.76 & 4.84 \\ 120 & & 4.52 & 5.45 & 6.28 & 6.86 & 7.37 & 7.73 & 7.97\end{array}$

Site index 80

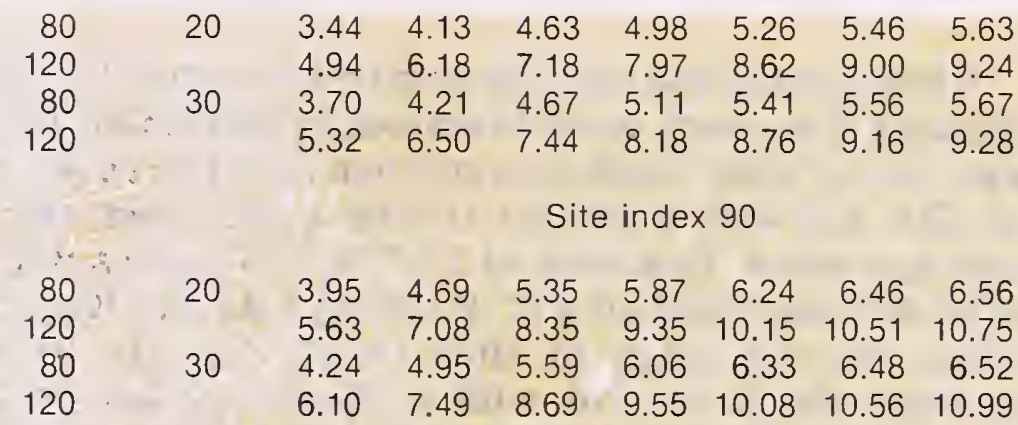

time. Periodic basal area increment increases as GSL increases from 40 to 140 , but the rate of increase diminishes as stand density increases. At GSL's above 140 , basal area increment declines on all sites. Periodic mean basal area growth also increases as site index increases. Moreover, the differences in basal area growth between site classes become progressively greater as GSL increases. Periodic mean basal area increment is greater with a 30-year cutting cycle than with a 20-year entry at all rotation ages and GSL's examined.

\section{Total Cubic-Foot Volume Increment}

Cubic-foot volume production is related to stand density, site quality, rotation age, and frequency of thinning (table 1). Although mean annual cubic volume increment increases as GSL and site index increase, the rate of increase diminishes as GSL increases, while the differences in growth between site classes becomes greater (fig. 3) (table 2). Cubic volume increment will apparently continue to increase slightly at GSL's above
Table 2.-Estimated mean annual total cubic foot volume increment per acre of southwestern ponderosa pine in relation to growing stock level, rotation age, cutting cycle, and site index

\begin{tabular}{lllllllll}
\hline $\begin{array}{l}\text { Rotation } \\
\text { age }\end{array}$ & $\begin{array}{c}\text { Cutting } \\
\text { cycle }\end{array}$ & 40 & 60 & 80 & 100 & 120 & 140 & 160 \\
\hline & & & & & & \multicolumn{6}{c}{ Growing stock level } \\
\hline
\end{tabular}

Site index 50

\begin{tabular}{rllllllll}
80 & 20 & 26.6 & 30.4 & 33.5 & 36.0 & 37.5 & 38.2 & 39.1 \\
120 & & 25.3 & 30.6 & 34.0 & 36.6 & 38.3 & 39.5 & 40.2 \\
80 & \multirow{3}{*}{30} & 27.5 & 31.6 & 34.0 & 35.9 & 37.5 & 38.8 & 39.1 \\
120 & & 26.2 & 31.3 & 35.1 & 37.1 & 38.3 & 38.9 & 39.1
\end{tabular}

Site index 60

$\begin{array}{rllllllll}80 & 20 & 31.6 & 36.6 & 40.9 & 44.2 & 46.7 & 48.2 & 49.2 \\ 120 & & 30.5 & 37.0 & 41.8 & 45.3 & 48.5 & 50.0 & 50.7 \\ 80 & 30 & 32.8 & 37.9 & 42.0 & 44.6 & 46.6 & 48.6 & 49.9 \\ 120 & & 31.3 & 38.2 & 43.6 & 47.0 & 49.5 & 51.0 & 52.5\end{array}$

Site index 70

$\begin{array}{rllllllll}80 & 20 & 37.5 & 44.0 & 48.9 & 52.4 & 56.1 & 58.7 & 60.0 \\ 120 & & 35.8 & 44.0 & 50.4 & 55.5 & 60.0 & 63.0 & 64.0 \\ 80 & 30 & 39.2 & 45.1 & 49.9 & 53.8 & 57.0 & 59.5 & 60.5\end{array}$

$\begin{array}{llllllll}120 & 37.7 & 45.4 & 52.3 & 57.2 & 61.4 & 64.4 & 66.4\end{array}$

Site index 80

$\begin{array}{rllllllll}80 & 20 & 43.0 & 51.6 & 57.9 & 62.2 & 65.8 & 68.2 & 70.4 \\ 120 & & 41.2 & 51.5 & 59.8 & 66.4 & 71.8 & 75.0 & 77.0 \\ 80 & 30 & 46.2 & 52.6 & 58.4 & 63.9 & 67.6 & 69.5 & 70.9 \\ 120 & & 44.3 & 54.2 & 62.0 & 68.2 & 73.0 & 76.3 & 77.3\end{array}$

Site index 90

$\begin{array}{rllllllll}80 & 20 & 49.4 & 58.6 & 66.9 & 73.4 & 78.0 & 80.8 & 82.0 \\ 120 & & 46.9 & 59.0 & 69.6 & 77.9 & 84.6 & 87.6 & 89.6 \\ 80 & 30 & 53.0 & 61.9 & 69.9 & 75.8 & 79.1 & 81.0 & 81.5 \\ 120 & & 50.8 & 62.4 & 72.4 & 79.6 & 84.0 & 88.0 & 91.6\end{array}$

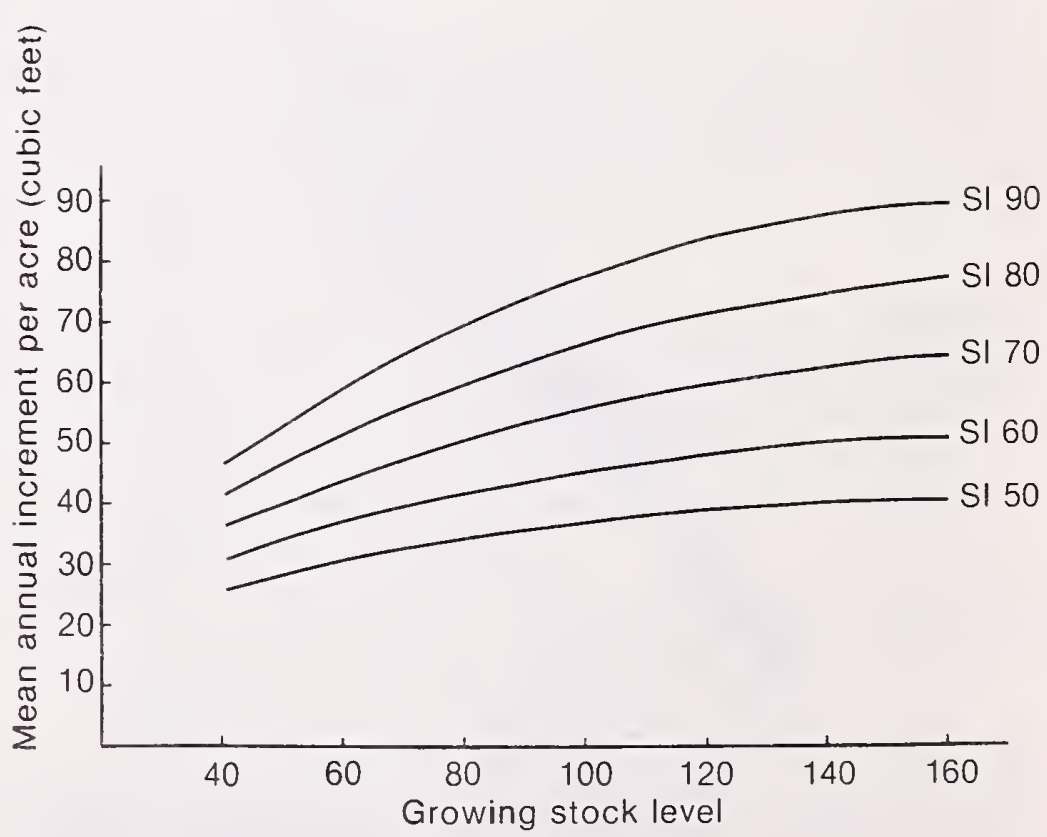

Figure 3.-Estimated mean annual total cubic-foot volume increment per acre of southwestern ponderosa pine in relation to GSL and site quality for a 120 -year rotation with a 20 -year thinning interval. 
Table 3.-Estimated total board foot volume production per acre of southwestern ponderosa pine in relation to growing stock level, rotation age, cutting cycle. and site index (trees 10 inches d.b.h. and larger to a variable top diameter)

\begin{tabular}{lllllllll}
\hline $\begin{array}{c}\text { Rotation } \\
\text { age }\end{array}$ & $\begin{array}{c}\text { Cutting } \\
\text { cycle }\end{array}$ & 40 & 60 & 80 & 100 & 120 & 140 & 160 \\
\hline
\end{tabular}

Site index 50

$\begin{array}{rrrrrrrrr}80 & 20 & 3.36 & 3.68 & 4.00 & 4.40 & 4.40 & 4.16 & 3.68 \\ 120 & & 8.40 & 9.84 & 10.80 & 11.28 & 11.28 & 10.56 & 9.60 \\ 80 & 30 & 3.28 & 3.60 & 3.84 & 4.08 & 3.92 & 3.60 & 3.04 \\ 120 & & 8.40 & 9.84 & 10.56 & 10.92 & 10.80 & 9.96 & 8.64 \\ & & & & & & & & \\ & & & & & & \\ & & & & & & & & \\ 80 & 20 & 4.48 & 5.04 & 5.44 & 5.76 & 6.00 & 6.00 & 5.76 \\ 120 & & 10.92 & 12.72 & 14.16 & 15.24 & 15.60 & 15.36 & 15.00 \\ 80 & 30 & 4.40 & 4.80 & 5.20 & 5.44 & 5.68 & 5.52 & 5.20 \\ 120 & & 10.68 & 12.72 & 13.80 & 14.52 & 14.76 & 14.64 & 14.40\end{array}$

Site index 70

$\begin{array}{rrrrrrrrr}80 & 20 & 5.60 & 6.24 & 6.72 & 7.20 & 7.60 & 8.00 & 8.16 \\ 120 & & 13.08 & 15.72 & 17.64 & 18.96 & 20.04 & 20.64 & 21.00 \\ 80 & 30 & 5.44 & 6.16 & 6.64 & 7.04 & 7.28 & 7.28 & 7.20 \\ 120 & & 13.56 & 15.96 & 17.88 & 19.08 & 19.92 & 20.16 & 20.40\end{array}$

Site index 80

$\begin{array}{rrrrrrrrr}80 & 20 & 6.80 & 7.68 & 8.48 & 9.04 & 9.44 & 9.92 & 10.24 \\ 120 & & 15.96 & 18.96 & 21.48 & 23.40 & 25.20 & 26.64 & 27.36 \\ 80 & 30 & 7.04 & 7.76 & 8.40 & 8.96 & 9.20 & 9.36 & 9.44 \\ 120 & & 17.04 & 19.68 & 22.08 & 24.24 & 25.44 & 26.04 & 26.40\end{array}$

Site index 90

$\begin{array}{rrrrrrrrr}80 & 20 & 8.08 & 9.20 & 10.24 & 11.04 & 11.84 & 12.32 & 12.64 \\ 120 & & 18.84 & 23.16 & 26.64 & 29.40 & 31.44 & 32.76 & 33.60 \\ 80 & 30 & 8.56 & 9.28 & 10.16 & 10.88 & 11.20 & 11.52 & 11.76 \\ 120 & & 20.64 & 23.64 & 26.76 & 29.52 & 30.96 & 31.92 & 32.40\end{array}$

160 on sites 70 and greater, but levels off or declines on site indexes less than 70 at GSL's greater than 160 . Cubic foot growth is generally unrelated to length of rotation or cutting cycle at all GSL's tested when site index is less than 70 . On site index 70 and greater lands, cubic-volume growth is greater on 120 -year rotation at GSL's greater than 60, but there are no practical differences between a 20- and 30-year cutting cycle (table 2).

\section{Board-Foot Volume Increment}

Board-foot volume production is related to all stand parameters evaluated (table 3). Mean annual sawtimber volume growth increases as stand density increases throughout the range of GSL's on site index 80 and 90 lands, but generally levels off on site index 70 lands at GSL 140, and declines on site index 50 and 60 lands at GSL's 100 and 120, respectively (fig. 4) (table 4).

Board-foot volume growth increases with site quality, and the differences in growth between site classes
Table 4.-Estimated mean annual board-foot volume increment per acre of southwestern ponderosa pine in relation to growing stock level, rotation age. cutting cycle, and site index (trees 10 inches d.b.h. and larger to a variable top diameter)

\begin{tabular}{ccccccccc}
\hline Rotation & Cutting & \multicolumn{5}{c}{ Growing stock level } \\
\cline { 3 - 9 } & $\begin{array}{c}\text { cycle } \\
\text { age }\end{array}$ & 40 & 60 & 80 & 100 & 120 & 140 & 160
\end{tabular}

\begin{tabular}{rllllllll}
\multicolumn{8}{c}{ Site index 50} \\
80 & 20 & 42 & 46 & 50 & 55 & 55 & 52 & 46 \\
120 & & 70 & 82 & 90 & 94 & 94 & 88 & 80 \\
80 & 30 & 41 & 45 & 48 & 51 & 49 & 45 & 38 \\
120 & & 70 & 82 & 88 & 91 & 90 & 83 & 72
\end{tabular}

Site index 60

$\begin{array}{rrrrrrrrr}80 & 20 & 56 & 63 & 68 & 72 & 75 & 75 & 72 \\ 120 & & 91 & 106 & 118 & 127 & 130 & 128 & 125 \\ 80 & 30 & 55 & 60 & 65 & 68 & 71 & 69 & 65 \\ 120 & & 89 & 106 & 115 & 121 & 123 & 122 & 120\end{array}$

Site index 70

$\begin{array}{rrrrrrrrr}80 & 20 & 70 & 78 & 84 & 90 & 95 & 100 & 102 \\ 120 & & 109 & 131 & 147 & 158 & 167 & 172 & 175 \\ 80 & 30 & 68 & 77 & 83 & 88 & 91 & 91 & 90 \\ 120 & & 113 & 133 & 149 & 159 & 166 & 168 & 170\end{array}$

Site index 80

$\begin{array}{rrrrrrrrr}80 & 20 & 85 & 96 & 106 & 113 & 118 & 124 & 128 \\ 120 & & 133 & 158 & 179 & 195 & 210 & 222 & 228 \\ 80 & 30 & 88 & 97 & 105 & 112 & 115 & 117 & 118 \\ 120 & & 142 & 164 & 184 & 202 & 212 & 217 & 220\end{array}$

Site index 90

$\begin{array}{rllllllll}80 & 20 & 101 & 115 & 128 & 138 & 148 & 154 & 158 \\ 120 & & 157 & 193 & 222 & 245 & 262 & 273 & 280 \\ 80 & 30 & 107 & 116 & 127 & 136 & 140 & 144 & 147 \\ 120 & & 172 & 197 & 223 & 246 & 258 & 266 & 270\end{array}$

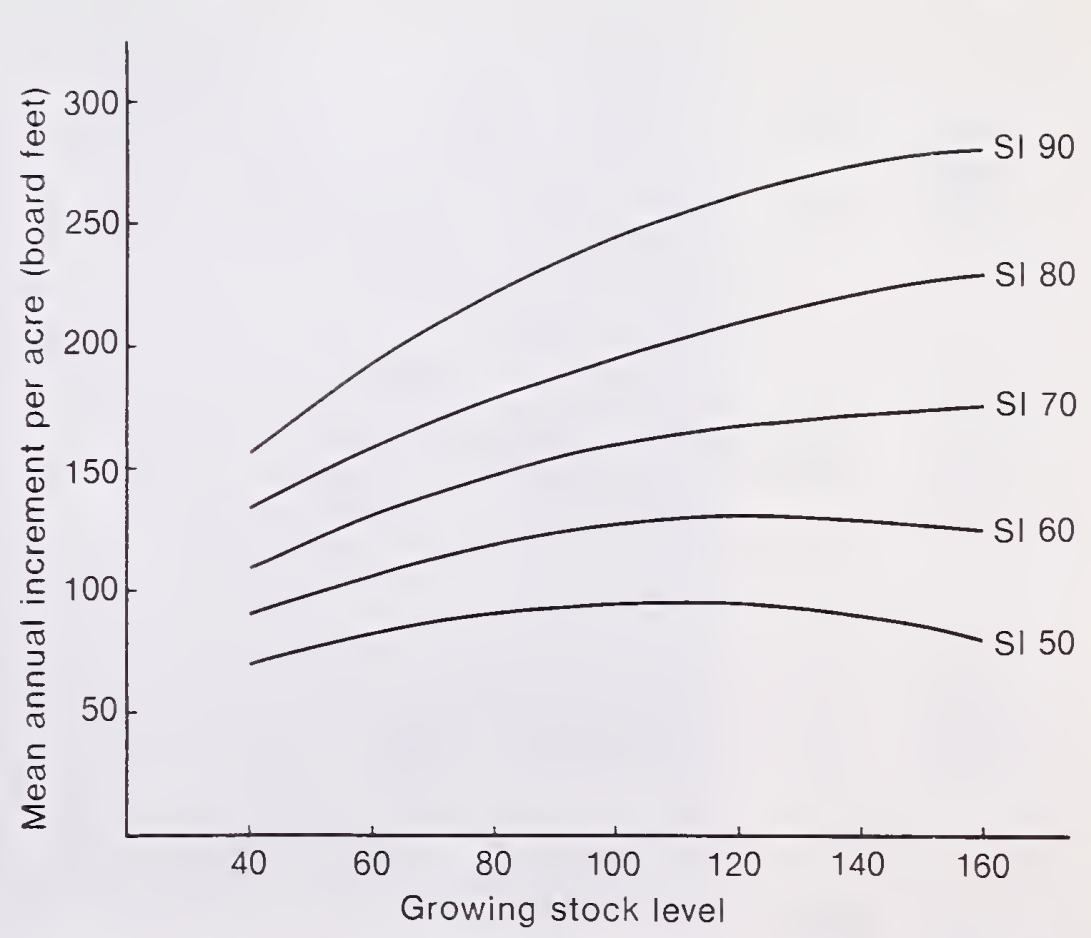

Figure 4. - Estimated mean annual board foot volume increment per acre of southwestern ponderosa pine in relation to GSL and site quality for a 120-year rotation with a 20 -year thinning interval. 
becomes greater as GSL increases. Throughout the range of GSL's tested, average annual board-foot increment per acre is always greater for all site classes on a 120 -year rotation than on 80-year rotation (fig. 5). There are no practical differences in board-foot volume growth between 20- and 30-year cutting cycles for the range of site indexes and GSL's tested (table 4).

\section{Maximizing Board-Foot Volume Yields}

What yields can be expected with intensive management of southwestern ponderosa pine to maximize timber production? If the objective is to integrate timber production with other resources uses, what are the timber tradeoffs? How can these objectives be attained with the fewest precommercial thinnings?

The largest volume production per acre $(33,600 \mathrm{fbm})$ is attained on site index 90 lands, at GSL 160, on a 120 -year rotation, with a 20 -year cutting cycle (table 3 ). These stands will contain about 72 trees per acre with an average d.b.h. of nearly 17 inches at rotation age (table 5).

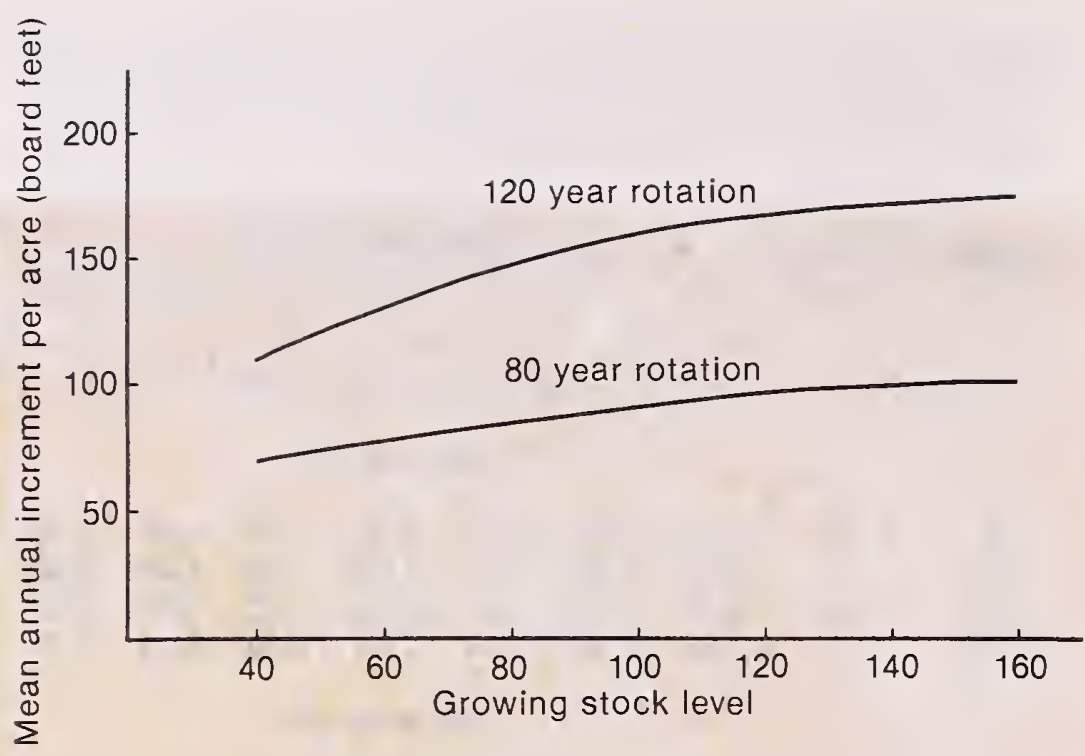

Figure 5.-Estimated mean annual board-foot volume increment per acre of southwestern ponderosa pine on site index 70 lands with a 20 -year thinning interval in relation to GSL and rotation age.

Table 5.-Estimated average diameter (inches) and number of trees per acre of southwestern ponderosa pine at final harvest in relation to growing stock level, rotation age, cutting cycle, and site index

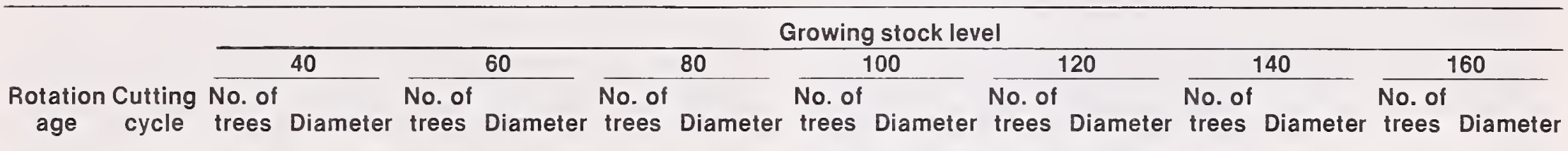

$\begin{array}{rrrrrrrr}80 & 20 & 22 & 16.5 & 39 & 14.8 & 64 & 13.3 \\ 120 & & 9 & 23.7 & 18 & 20.6 & 29 & 18.5 \\ 80 & 30 & 24 & 15.9 & 45 & 14.1 & 72 & 12.7 \\ 120 & & 10 & 22.9 & 20 & 19.6 & 33 & 17.6\end{array}$

Site index 50

$\begin{array}{rrrr}80 & 20 & 21 & 17.0 \\ 120 & & 9 & 24.4 \\ 80 & 30 & 23 & 16.4 \\ 120 & & 10 & 23.5\end{array}$

$\begin{array}{rrrr}80 & 20 & 20 & 17.5 \\ 120 & & 8 & 25.4 \\ 80 & 30 & 21 & 17.1 \\ 120 & & 9 & 24.8\end{array}$

$\begin{array}{rrrrrr}80 & 20 & 18 & 18.3 & 34 & 16.4 \\ 120 & & 7 & 26.9 & 14 & 23.5 \\ 80 & 30 & 20 & 17.7 & 37 & 15.8 \\ 120 & & 8 & 25.8 & 15 & 22.7\end{array}$

$\begin{array}{rrrr}80 & 20 & 17 & 18.9 \\ 120 & & 7 & 27.6 \\ 80 & 30 & 20 & 17.9 \\ 120 & & 8 & 26.6\end{array}$

$\begin{array}{rrrrrrrr}92 & 12.3 & 119 & 11.5 & 153 & 10.8 & 189 & 10.2 \\ 46 & 16.4 & 63 & 15.3 & 89 & 13.9 & 123 & 12.6 \\ 101 & 11.7 & 131 & 11.0 & 165 & 10.4 & 202 & 9.8 \\ 50 & 15.9 & 67 & 14.9 & 94 & 13.6 & 128 & 12.4\end{array}$

Site index 60

$\begin{array}{rrrrrrrr}83 & 13.0 & 111 & 12.1 & 145 & 11.3 & 180 & 10.7 \\ 40 & 17.6 & 56 & 16.3 & 77 & 15.0 & 105 & 13.7 \\ 92 & 12.4 & 124 & 11.5 & 155 & 10.9 & 192 & 10.3\end{array}$

Site index 70

$\begin{array}{rrrrrrrr}80 & 13.3 & 106 & 12.6 & 132 & 12.0 & 168 & 11.2 \\ 37 & 18.5 & 52 & 17.1 & 66 & 16.2 & 90 & 14.9 \\ 90 & 12.7 & 120 & 11.9 & 147 & 11.4 & 183 & 10.7\end{array}$

Site index 80

$\begin{array}{rrrrrrrr}77 & 13.7 & 100 & 13.1 & 130 & 12.3 & 154 & 11.9 \\ 34 & 19.4 & 46 & 18.2 & 62 & 16.9 & 79 & 15.9 \\ 85 & 13.2 & 110 & 12.6 & 142 & 11.8 & 174 & 11.2 \\ 38 & 18.5 & 50 & 17.5 & 68 & 16.2 & 87 & 15.3\end{array}$

Site index 90

$\begin{array}{rrrrrrrr}71 & 14.4 & 94 & 13.6 & 119 & 13.0 & 148 & 12.3 \\ 30 & 20.7 & 41 & 19.2 & 55 & 18.0 & 72 & 16.8 \\ 79 & 13.8 & 106 & 13.0 & 132 & 12.4 & 165 & 11.7 \\ 34 & 19.5 & 46 & 18.3 & 60 & 17.3 & 78 & 16.2\end{array}$


Volume production substantially declines when GSL is reduced below 160 on site index 70,80 , and 90 lands. The decline is greater with each successive reduction in stand density. Maximum volume production is at GSL's 100 and 120, on site index 50 and 60 lands, respectively, with a 20-year cutting cycle (table 3) (fig. 6).

Table 3 also shows the amount volume given up as GSL is reduced from the level of maximum production to GSL 40 for all combinations of stand parameters examined. Moreover, it shows that more volume can be produced over the same time span with 120 -year rotations than with 80 -year rotations. For example, on site index 90 lands, maximum board-foot volume production per acre from two 120 -year rotations, or 240 years, would be $67,200 \mathrm{fbm}$, compared with $37,900 \mathrm{fbm}$ on three 80-year rotations, also 240 years.

Whether the board-foot volume production potentials can be achieved depends largely on how much money can be invested in thinning. It is assumed that once a stand reaches a minimum merchantable size of 10 inches average d.b.h., market conditions permit intermediate thinnings to be made as scheduled. If economic constraints limit managers to only one precommercial thinning in the life of the stand, their options are severely restricted. For example, on site index 50 to 60 lands, stand density must be reduced to GSL 40 and the cutting cycle increased to 30 years (table 6). On site index 70 and 80 lands, a GSL of 60 can be maintained with a 30-year cutting cycle, and on site index 90 lands, a GSL of 100 can be maintained.
Table 6.-Number of precommercial thinnings of southwestern ponderosa pine in relation to growing stock level, cutting cycle, and site index

\begin{tabular}{|c|c|c|c|c|c|c|c|c|}
\hline \multirow{2}{*}{$\begin{array}{c}\text { Cutting } \\
\text { cycle }\end{array}$} & \multirow{2}{*}{$\begin{array}{c}\text { Site } \\
\text { index }\end{array}$} & \multicolumn{7}{|c|}{ Growing stock level } \\
\hline & & 40 & 60 & 80 & 100 & 120 & 140 & 160 \\
\hline \multicolumn{9}{|l|}{ years } \\
\hline \multirow{5}{*}{20} & 50 & 2 & 2 & 3 & 3 & 4 & 4 & 4 \\
\hline & 60 & 2 & 2 & 2 & 3 & 3 & 4 & 4 \\
\hline & 70 & 2 & 2 & 2 & 3 & 3 & 3 & 4 \\
\hline & 80 & 2 & 2 & 2 & 2 & 3 & 3 & 4 \\
\hline & 90 & 1 & 1 & 2 & 2 & 2 & 3 & 3 \\
\hline \multirow[t]{5}{*}{30} & 50 & 1 & 2 & 2 & 2 & 3 & 3 & 3 \\
\hline & 60 & 1 & 2 & 2 & 2 & 2 & 3 & 3 \\
\hline & 70 & 1 & 1 & 2 & 2 & 2 & 2 & 3 \\
\hline & 80 & 1 & 1 & 2 & 2 & 2 & 2 & 2 \\
\hline & 90 & 1 & 1 & 1 & 1 & 2 & 2 & 2 \\
\hline
\end{tabular}

Thinnings to a constant GSL have been assumed up to now. However, if only one precommercial thinning is possible, managers can increase their flexibility by changing GSL's with successive reentries. For example, on site index 70 and 80 lands with a 30 -year cutting cycle, stand density is initially reduced to GSL 60. At the time of the second thinning, GSL is increased to 80 , and increased to GSL 100 with the third thinning. Volume production will be less than maximum, but reasonably close to the volume available from a stand maintained at a constant GSL 100. Attempts to raise the GSL to 100 at the time of the second entry into the

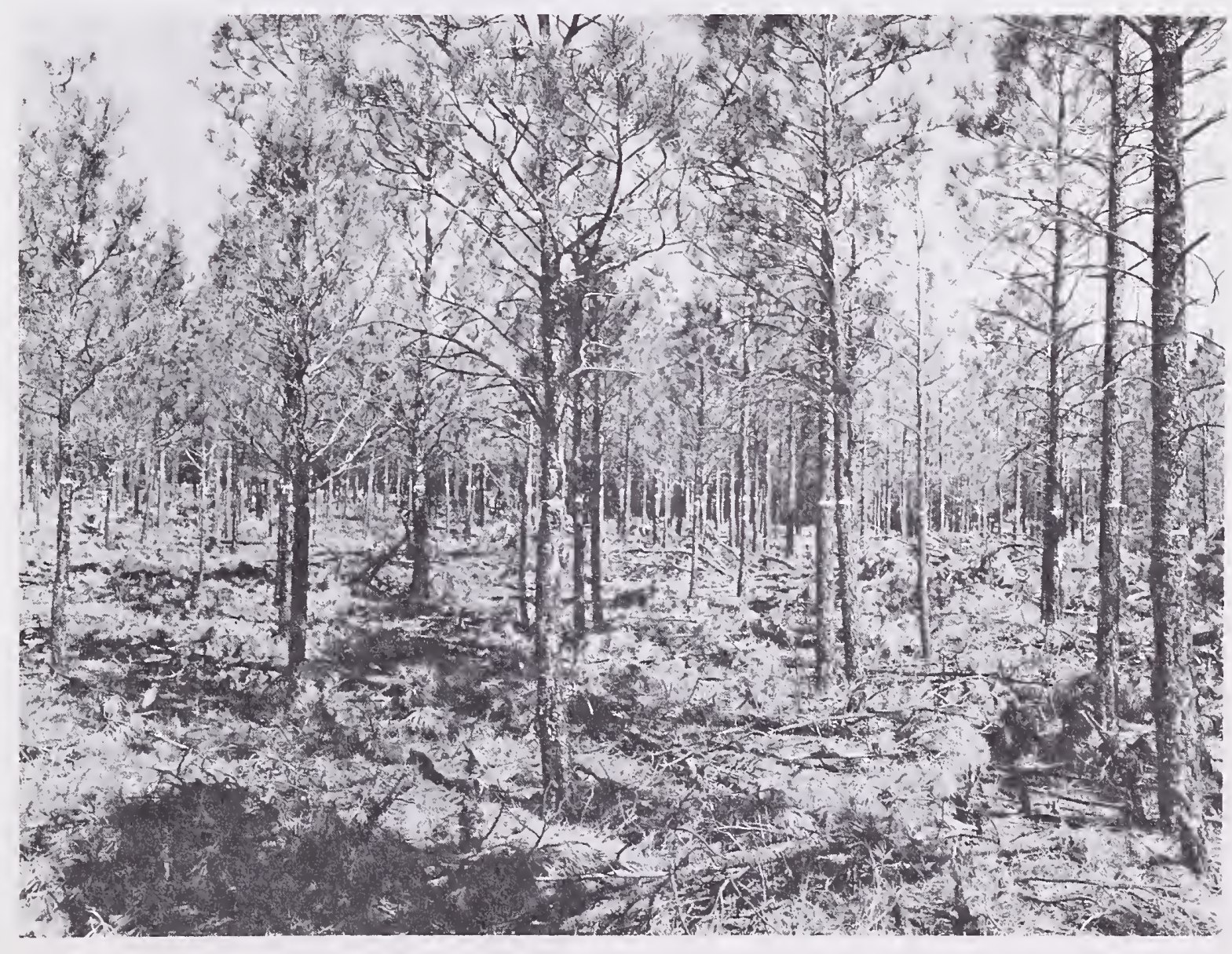

Figure 6.-Second growth southwestern ponderosa pine on site index 60 lands (Meyer 1961) thinned to GSL 120, Taylor Woods near Flagstaff, Ariz. Stand was about 45 years old when thinned in 1962. 
stand would result in a second precommercial thinning. By following this procedure, managers can increase GSL on site index 50 and 60 lands from 40 to 80 .

The manager has another option if only one precommercial thinning is possible. The initial thinning can be made on schedule and the second entry delayed until the stand reaches minimum merchantable size. This will increase the second thinning interval to 40 years or more, increase the length of the rotation, and result in less than maximum volume production.

Where economic conditions permit investment of funds in two precommercial thinnings, the manager has the opportunity to maximize timber production on site index 50 to 90 lands, with 30-year thinning schedule.

\section{Tradeoffs to Increase Values of Other Resources}

Understory vegetation in southwestern ponderosa pine is an important forage source for livestock and big game animals, but as overstory density increases, the productivity of the understory decreases. This inverse relationship is generally shown to be curvilinear (Pearson 1964, Jameson 1969, Clary 1969). Generally, herbage yields on productive sites can vary from 50 to 75 pounds per acre under dense timber stands (basal area per acre of 140 square feet) to 1,000 to 1,200 pounds per acre on moderately grazed open grasslands (Clary 1975) (fig. 7). High herbage production on these sites can be expected in clearcut openings until new tree regeneration becomes limiting. Actual changes in herbage production will vary considerably, however, depending upon habitat type, successional stage, and past grazing history, as well as overstory density.

In partially cut or thinned stands, herbage production generally is substantially greater than under uncut stands only when stand density is reduced to 70 square feet or less of basal area per acre, and differences in herbage production become progressively greater as

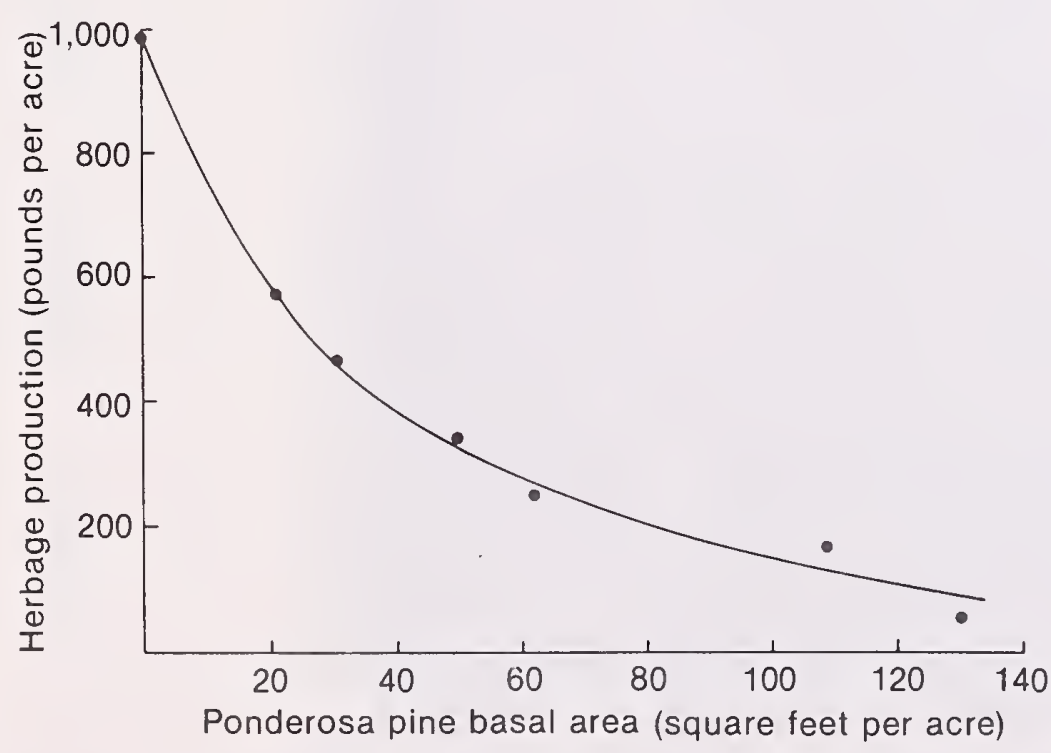

Figure 7.- Relation of herbage production to basal area of southwestern ponderosa pine on the Wild Bill range north of Flagstaff, Ariz. (Clary 1975).

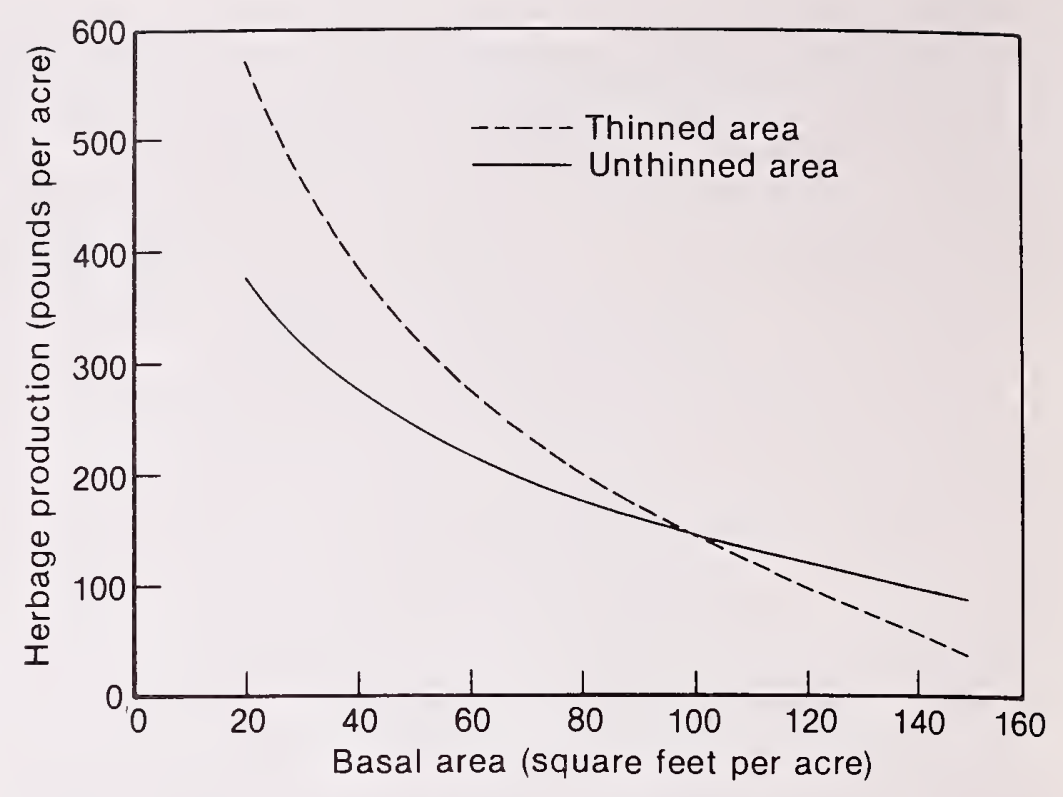

Figure 8.-Relationship between herbage production and basal area of southwest ponderosa pine on thinned and thinned areas, Beaver Creek Watershed near Flagstaff, Ariz. (Clary and Ffolliott 1966).

stand density in the thinned stands is reduced to 20 square feet of basal area per acre (Clary and Ffolliott 1966, Pearson 1967) (fig. 8). Moreover, herbage production under partially cut or thinned stands usually peaks about 5 years after treatment and will exceed production in uncut stands for only 10 to 15 years (Reynolds 1962).

Although no methods or data are available to quantify changes in understory herbage production under southwestern ponderosa pine for the range of GSL's, site indexes, rotation ages, and cutting cycles examined here, some general conclusions can be drawn. To increase average herbage production to even moderate levels ( 350 to 400 pounds per acre), the manager must be willing to reduce basal area stocking per acre to GSL 60 or less (fig. 9). To maintain forage production, the manager must be able to make additional cuts in the stand at intervals of at least every 20 years.

Southwestern ponderosa pine forests yield less water than subalpine and mixed conifer forests (Rich and Thompson 1974, Leaf 1975). The proportion of water available for streamflow ( 3 to 5 inches) to precipitation (20 to 25 inches) is low because of high evapotranspiration demand from vegetation during a long, warm growing season, and the variability of precipitation (Hibbert 1979). Water yield is derived mostly from snowmelt, and snowfall regimes are highly variable in the Southwest. Streamflow is greatest when winter snowfall is sufficient to maintain a continuous snowpack and soil moisture is recharged during the spring melt. Major runoff also occurs when rain falls on snow. Regimes that produce intermittent snowpacksnowfall followed by dry periods that melt the snow, or years of light snowfall-contribute little to streamflow. Weather from snowmelt to July is usually dry, and late summer rains only partially replenish losses from evapotranspiration.

The potential for increasing streamflow in ponderosa pine forests is also low. The largest increases ( 1 to 
2 inches) occur when timber is harvested by clearcutting (Brown et al. 1974). The most effective pattern of timber harvest for increased water yields in ponderosa pine forests when precipitation is largely snow and redistribution by wind is significant is to clearcut about $30 \%$ to $40 \%$ of a drainage in small, irregularshaped patches about five times tree height across, interspersed with uncut patches of about five to eight tree heights across (Gary 1975). If snowfall is not significant or redistribution of snow by wind is not a factor, larger clearcut openings are more effective in increasing streamflow. In this case, the increase in streamflow is largely a result of the reduction in consumptive use by vegetation. With harvest cutting methods that leave a residual stand or thinning, the increase in water yield will be less than with clearcutting and generally in an inverse proportion to the amount of basal area left.

Based on information available from research, observations, and experience, it is clear that stand density must be reduced to and maintained at low stocking levels (GSL's of 60 or less) to benefit forage and water resources. For example, on site index 80 lands, at GSL 80, with a 120-year rotation, and a 20-year thinning schedule, 5,880 fewer fbm per acre will be produced than at GSL 160 . If the GSL is reduced to 40 , the loss in volume production per acre is 11,400 fbm. Foreground landscape esthetics and developed and dispersed recreation opportunities are generally improved at moderate (GSL 80 to 100) stocking levels. Considerable timber volume is given up, however, at both low to moderate stocking levels.

Middleground and background landscapes require combinations of cleared openings, high and low stocking levels, and uncut timber to provide the variety and contrast that is visually pleasing. Some wildlife species require openings, others open-standing timber, while the habitat still of others is devastated by any kind of timber cutting. But until the habitat requirements of specific wildlife species are better known, the benefits and losses to wildlife cannot be determined for stand parameters examined here.

\section{Management Caution}

This simulation program estimates growth responses to different stand parameters that appear reasonable and consistent within the limits of current knowledge, but no southwestern ponderosa pine stand has been under management for a long time, and simulation extends beyond the limits of the available data base. Comparisons of estimates with actual values from plots established to provide growth information will be needed to verify simulated responses.

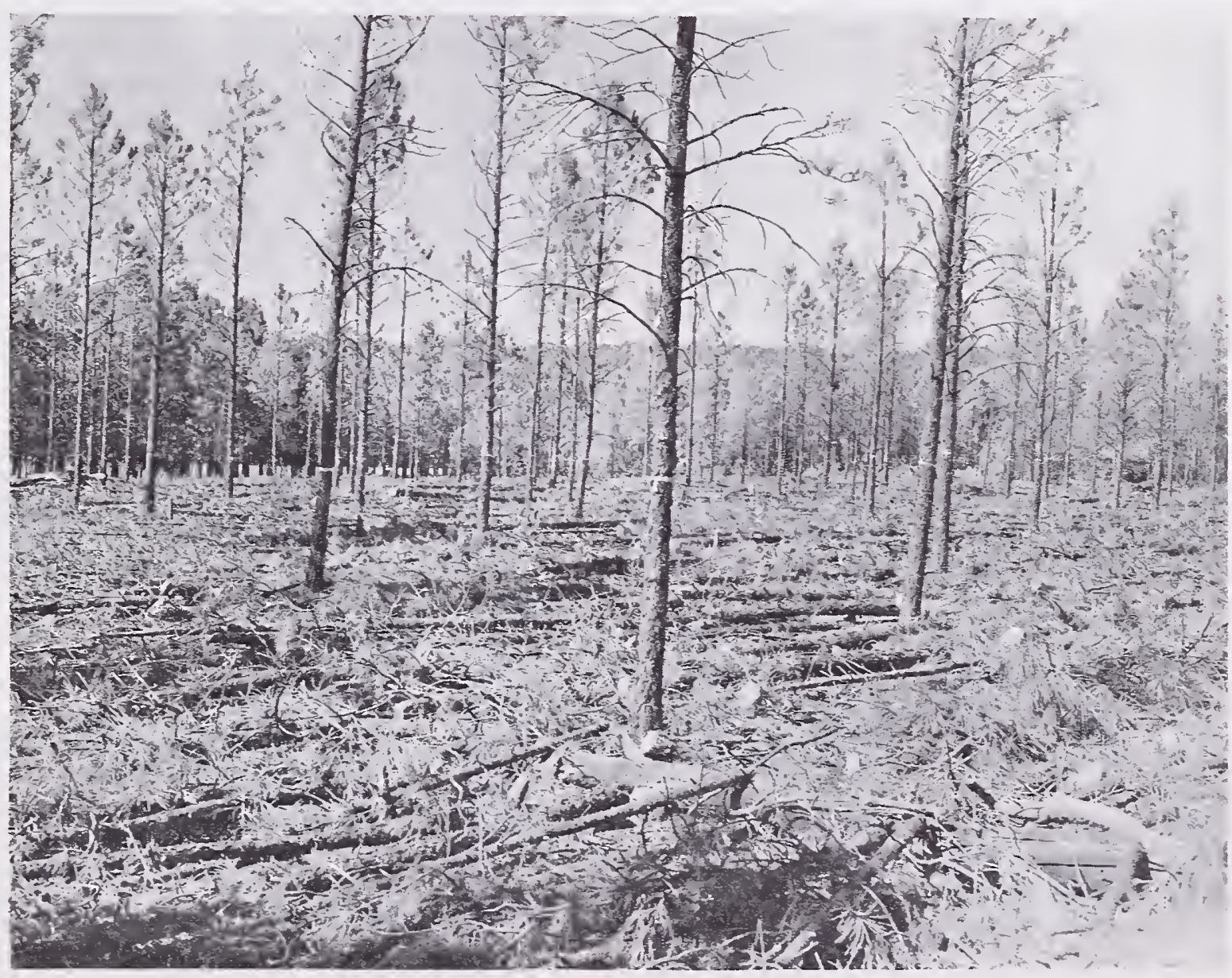

Figure 9.-Second-growth southwestern ponderosa pine on site index 60 lands (Meyer 1961) thinned to GSL 30 , Taylor Woods near Flagstaff, Ariz. Stand was about 45 years old when thinned in 1962. 


\section{Literature Cited}

Brown, Harry E., Malchus B. Baker, James R. Rogers, Warren P. Clary, J. L. Kovner, Frederic R. Larson, Charles C. Avery, and Ralph E. Campbell. 1972. Opportunities for increasing water yields and other multiple-use values of ponderosa pine forest lands. USDA Forest Service Research Paper RM-129, 36 p. Rocky Mountain Forest and Range Experiment Station, Fort Collins, Colo.

Choate, Grover A. 1965. Forests in Utah. USDA Forest Service Resource Bulletin INT-4, 61 p. Intermountain Forest and Range Experiment Station, Ogden, Utah.

Choate, Grover A. 1966. New Mexico's forest resource. USDA Forest Service Resource Bulletin INT-5, 60 p. Intermountain Forest and Range Experiment Station, Ogden, Utah.

Clary, Warren P. 1969. Increasing sampling precision for some herbage variables through knowledge of the timber overstory. Journal of Range Management 22:200-201.

Clary, Warren P. 1975. Range management and its ecological basis in the ponderosa pine type of Arizona: The status of our knowledge. USDA Forest Service Research Paper RM-158, 35 p. Rocky Mountain Forest and Range Experiment Station, Fort Collins, Colo.

Clary, Warren P., and Peter F. Ffolliott. 1966. Differences in herbage-timber relationships between thinned and unthinned ponderosa pine stands. USDA Forest Service Research Note RM-74, 4 p. Rocky Mountain Forest and Range Experiment Station, Fort Collins, Colo.

Edminster, Carleton B. 1978. RMYLD: Computation of yield tables for even-aged and two-storied stands. USDA Forest Service Research Paper RM-199, 26 p. Rocky Mountain Forest and Range Experiment Station, Fort Collins, Colo.

Gary, Howard L. 1975. Watershed management problems and opportunities for the Front Range ponderosa pine zone: The status of our knowledge. USDA Forest Service Research Paper RM-139, 32 p. Rocky Mountain Forest and Range Experiment Station, Fort Collins, Colo.

Hawksworth, Frank G. 1977. The 6-class dwarf mistletoe rating system. USDA Forest Service General Technical Report RM-48, 7 p. Rocky Mountain Forest and Range Experiment Station, Fort Collins, Colo.

Hibbert, Alden R. 1979. Managing vegetation to increase flow in the Colorado River basin. USDA Forest Service General Technical Report RM-66, 27 p. Rocky Mountain Forest and Range Experiment Station, Fort Collins, Colo.

Jameson, Donald A. 1967. The relationship of tree overstory and herbaceous understory vegetation. Journal of Range Management 20:247-249.

Leaf, Charles F. 1975. Watershed management in the Rocky Mountain subalpine zone: The status of our knowledge. USDA Forest Service Research Paper RM-107, 23 p. Rocky Mountain Forest and Range Experiment Station, Fort Collins, Colo.
Meyer, Walter H. 1961. Yield of even-aged stands of ponderosa pine. U.S. Department of Agriculture Technical Bulletin 630, 59 p. Washington, D.C.

Miller, Robert L., and Grover A. Choate. 1964. The forest resource of Colorado. USDA Forest Service Resource Bulletin INT-3, 55 p. Intermountain Forest and Range Experiment Station, Ogden, Utah.

Myers, Clifford A. 1963. Volume, taper, and related tables for southwestern ponderosa pine. USDA Forest Service Research Paper RM-2, 24 p. (Revised 1972). Rocky Mountain Forest and Range Experiment Station, Fort Collins, Colo.

Myers, Clifford A. 1971. Field and computer procedures for managed-stand yield tables. USDA Forest Service Research Paper RM-79, 24 p. Rocky Mountain Forest and Range Experiment Station, Fort Collins, Colo.

Myers, Clifford A., Carleton B. Edminster, and Frank G. Hawksworth. 1976. SWYLD2: Yield tables for evenaged and two-storied stands of southwestern ponderosa pine, including effects of dwarf mistletoe. USDA Forest Service Research Paper RM-163, 25 p. Rocky Mountain Forest and Range Experiment Station, Fort Collins, Colo.

Pearson, G. A. 1950. Management of ponderosa pine in the Southwest. U.S. Department of Agriculture Monograph 6, 218 p. Washington, D.C.

Pearson, Henry A. 1964. Studies of forest digestibility under ponderosa pine stands. Society of American Foresters Proceedings 1964:71-73.

Pearson, Henry A. 1967. Forage and beef production from ponderosa pine range in the Southwest. p. 50. In Abstracts of Papers, 20th Annual Meeting, American Society of Range Management, [Seattle, Washington February 14-17, 1967]. Journal of Range Management, $71 \mathrm{p}$.

Reynolds, Hudson G. 1962. Effect of logging on understory vegetation and deer use in a ponderosa pine forest of Arizona. U.S. Department of Agriculture, Forest Service, Rocky Mountain Forest and Range Experiment Station, Research Note 80, 7 p. Fort Collins, Colorado.

Rich, Lowell R., and J. R. Thompson. 1974. Watershed management in Arizona's mixed conifer forests: The status of our knowledge. USDA Forest Service Research Paper RM-130, 15 p. Rocky Mountain Forest and Range Experiment Station, Fort Collins, Colo.

Schubert, Gilbert H. 1971. Growth response of evenaged ponderosa pine related to stand density levels. Journal of Forestry 69:857-860.

Schubert, Gilbert H. 1973. Southwestern ponderosa pine. p. 45-46. In Silvicultural systems for the major forest types of the United States. U.S. Department of Agriculture, Agricultural Handbook 445, 114 p.

Schubert, Gilbert H. 1974. Silviculture of southwestern ponderosa pine: The status of our knowledge. USDA Forest Service Research Paper RM-123, 71 p. Rocky Mountain Forest and Range Experiment Station, Fort Collins, Colo.

Spencer, John S., Jr. 1966. Arizona's forests. USDA Forest Service Resource Bulletin INT-6, 56 p. Intermountain Forest and Range Experiment Station, Ogden, Utah. 


\section{Appendix}

Table A-1. - Basal areas (square feet per acre) after intermediate cutting in relation to average stand diameter (inches) and growing stock level

\begin{tabular}{|c|c|c|c|c|c|c|c|c|c|c|c|}
\hline \multirow{2}{*}{$\begin{array}{l}\text { Average stand } \\
\text { d.b.h. after } \\
\text { cutting }\end{array}$} & \multicolumn{11}{|c|}{ Growing stock level } \\
\hline & 40 & 50 & 60 & 70 & 80 & 90 & 100 & 110 & 120 & 140 & 160 \\
\hline 2 & 6.0 & 7.5 & 9.1 & 10.6 & 12.1 & 13.6 & 15.1 & 16.7 & 18.2 & 21.2 & 24.2 \\
\hline 3 & 11.8 & 14.8 & 17.7 & 20.6 & 23.6 & 26.6 & 29.5 & 32.4 & 35.4 & 41.5 & 47.4 \\
\hline 4 & 17.6 & 22.0 & 26.4 & 30.8 & 35.2 & 39.6 & 44.0 & 48.4 & 52.8 & 61.6 & 70.4 \\
\hline 5 & 23.4 & 29.2 & 35.0 & 40.9 & 46.7 & 52.5 & 58.4 & 64.2 & 70.0 & 81.9 & 93.6 \\
\hline 6 & 28.3 & 35.4 & 42.4 & 49.5 & 56.6 & 63.7 & 70.8 & 77.8 & 84.9 & 99.0 & 113.2 \\
\hline 7 & 32.7 & 40.9 & 49.1 & 57.3 & 65.5 & 73.7 & 81.9 & 90.1 & 98.2 & 114.4 & 130.8 \\
\hline 8 & 36.2 & 45.3 & 54.4 & 63.4 & 72.5 & 81.6 & 90.6 & 99.7 & 108.8 & 126.9 & 145.0 \\
\hline 9 & 38.8 & 48.4 & 58.1 & 67.8 & 77.5 & 87.2 & 96.9 & 106.6 & 116.2 & 135.6 & 155.0 \\
\hline $10+$ & 40.0 & 50.0 & 60.0 & 70.0 & 80.0 & 90.0 & 100.0 & 110.0 & 120.0 & 140.0 & 160.0 \\
\hline
\end{tabular}

Table A.2. - Number of trees per acre in relation to average stand diameter (inches) and grow-

ing stock level

\begin{tabular}{|c|c|c|c|c|c|c|c|c|c|c|c|}
\hline \multirow{2}{*}{$\begin{array}{l}\text { Average stand } \\
\text { d.b.h. after } \\
\text { thinning }\end{array}$} & \multicolumn{11}{|c|}{ Growing stock levels } \\
\hline & 40 & 50 & 60 & 70 & 80 & 90 & 100 & 110 & 120 & 140 & 160 \\
\hline 2 & 277 & 345 & 418 & 488 & 553 & 626 & 692 & 767 & 836 & 968 & 1.107 \\
\hline 3 & 241 & 301 & 360 & 420 & 481 & 542 & 601 & 660 & 721 & 843 & 964 \\
\hline 4 & 202 & 252 & 302 & 353 & 403 & 454 & 504 & 554 & 605 & 707 & 808 \\
\hline 5 & 172 & 214 & 257 & 300 & 342 & 384 & 428 & 471 & 513 & 601 & 687 \\
\hline 6 & 144 & 180 & 216 & 252 & 288 & 324 & 361 & 396 & 432 & 505 & 577 \\
\hline 7 & 122 & 153 & 184 & 214 & 245 & 276 & 306 & 337 & 367 & 428 & 489 \\
\hline 8 & 104 & 130 & 156 & 182 & 208 & 234 & 260 & 286 & 312 & 364 & 415 \\
\hline 9 & 88 & 110 & 132 & 154 & 175 & 197 & 219 & 241 & 263 & 307 & 351 \\
\hline 10 & 73 & 92 & 110 & 128 & 147 & 165 & 183 & 202 & 220 & 257 & 293 \\
\hline
\end{tabular}

Table A.3.-Average distance (feet) between residual trees in relation to average stand diameter (inches) and growing stock level

\begin{tabular}{|c|c|c|c|c|c|c|c|c|c|c|c|}
\hline \multirow{2}{*}{$\begin{array}{l}\text { Average stand } \\
\text { d.b.h. after } \\
\text { thinning }\end{array}$} & \multicolumn{11}{|c|}{ Growing stock level } \\
\hline & 40 & 50 & 60 & 70 & 80 & 90 & 100 & 110 & 120 & 140 & 160 \\
\hline 2 & 12.5 & 11.1 & 10.2 & 9.4 & 8.8 & 8.3 & 7.8 & 7.5 & 7.2 & 6.7 & 6.3 \\
\hline 3 & 13.4 & 12.0 & 11.0 & 10.2 & 9.5 & 9.0 & 8.5 & 8.1 & 7.8 & 7.2 & 6.7 \\
\hline 4 & 14.7 & 13.2 & 12.0 & 11.1 & 10.4 & 9.8 & 9.3 & 8.9 & 8.5 & 7.9 & 7.3 \\
\hline 5 & 15.9 & 14.4 & 13.0 & 12.0 & 11.3 & 10.6 & 10.1 & 9.6 & 9.2 & 8.5 & 8.0 \\
\hline 6 & 17.4 & 15.6 & 14.4 & 13.2 & 12.3 & 11.6 & 11.0 & 10.5 & 10.0 & 9.3 & 8.7 \\
\hline 7 & 18.9 & 16.9 & 15.4 & 14.3 & 13.3 & 12.6 & 11.9 & 11.4 & 10.9 & 10.1 & 9.4 \\
\hline 8 & 20.5 & 18.3 & 16.7 & 15.5 & 14.5 & 13.6 & 13.0 & 12.3 & 11.8 & 10.9 & 10.2 \\
\hline 9 & 22.3 & 20.1 & 18.2 & 16.8 & 15.8 & 14.9 & 14.1 & 13.4 & 12.9 & 11.9 & 11.1 \\
\hline 10 & 24.4 & 21.8 & 20.1 & 18.4 & 17.2 & 16.2 & 15.4 & 14.7 & 14.1 & 13.0 & 12.2 \\
\hline
\end{tabular}




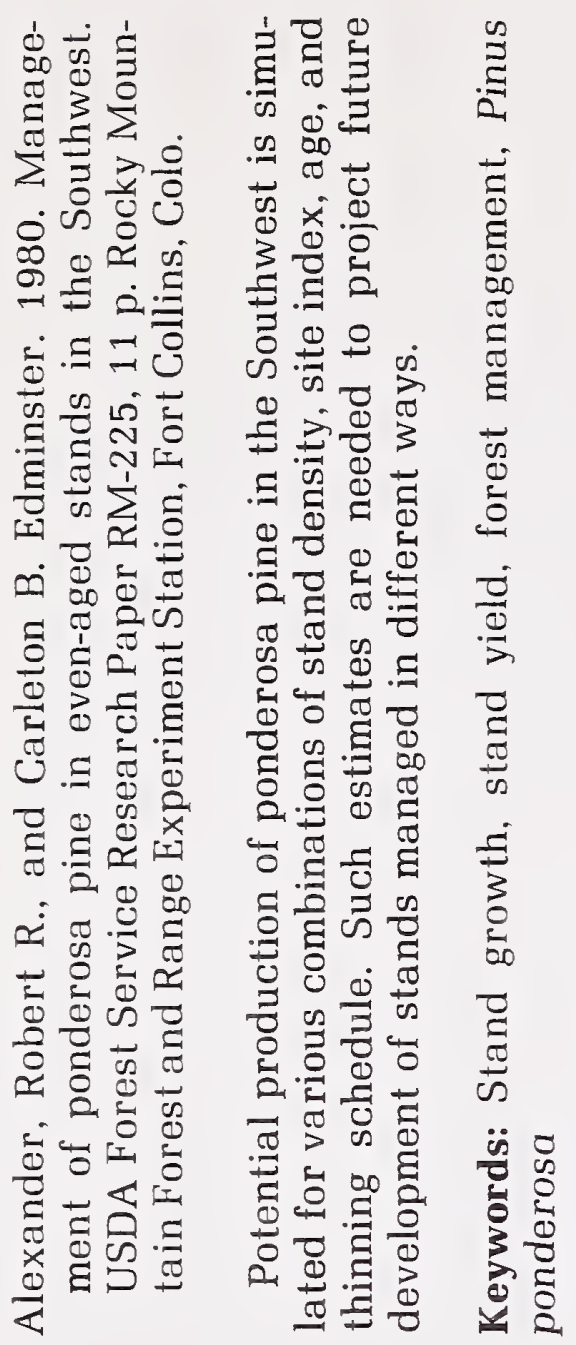

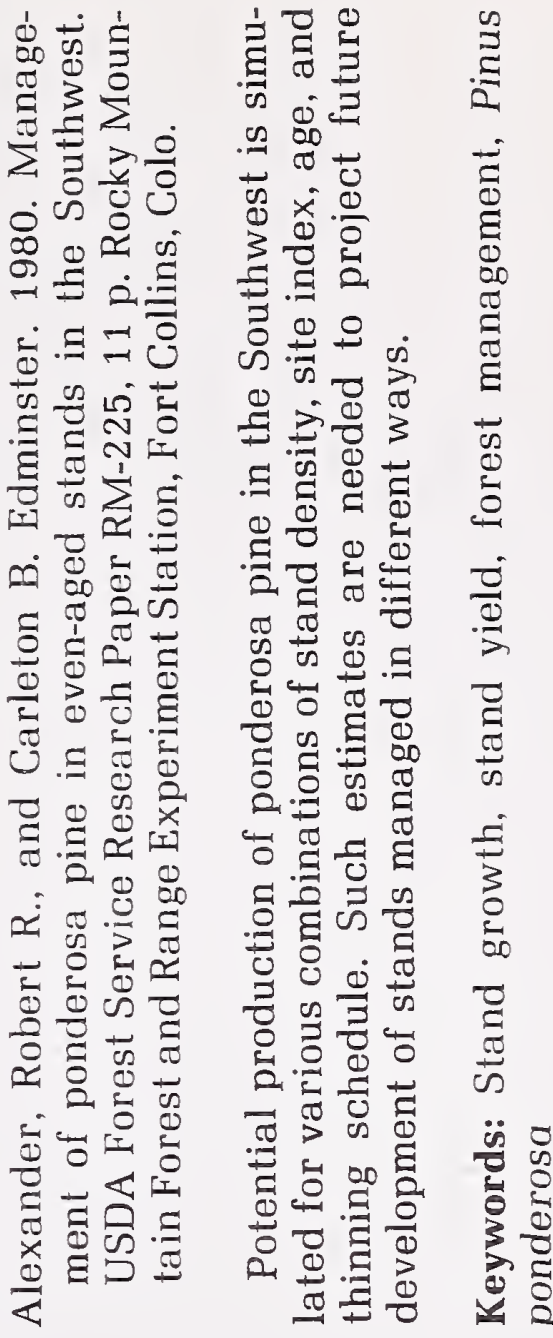

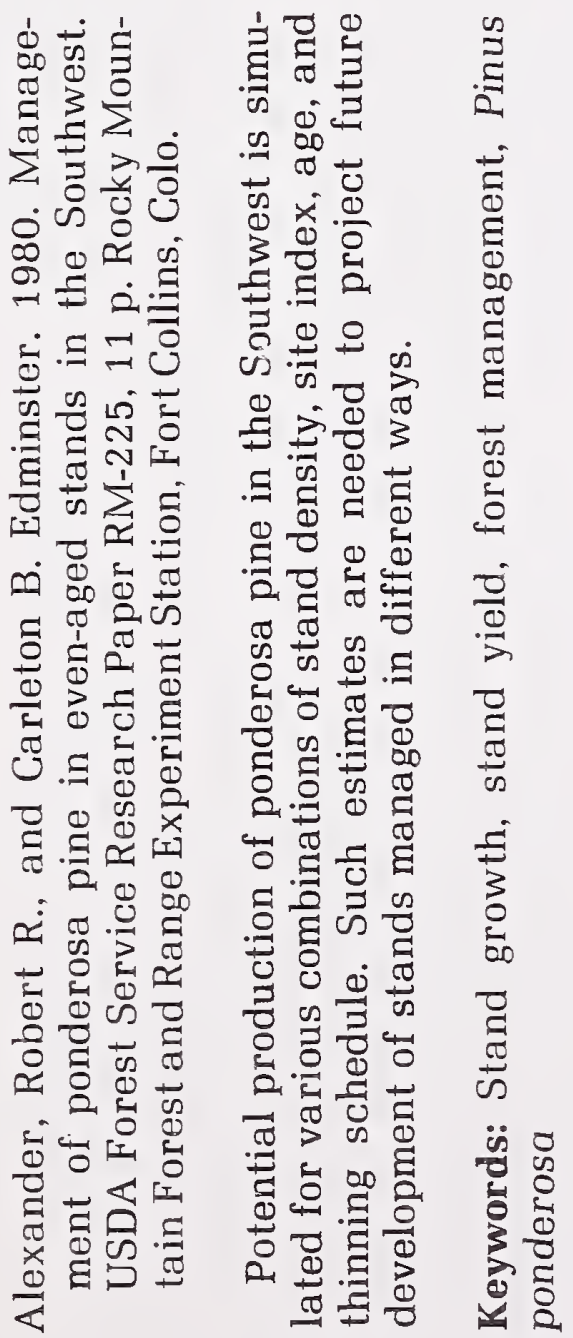

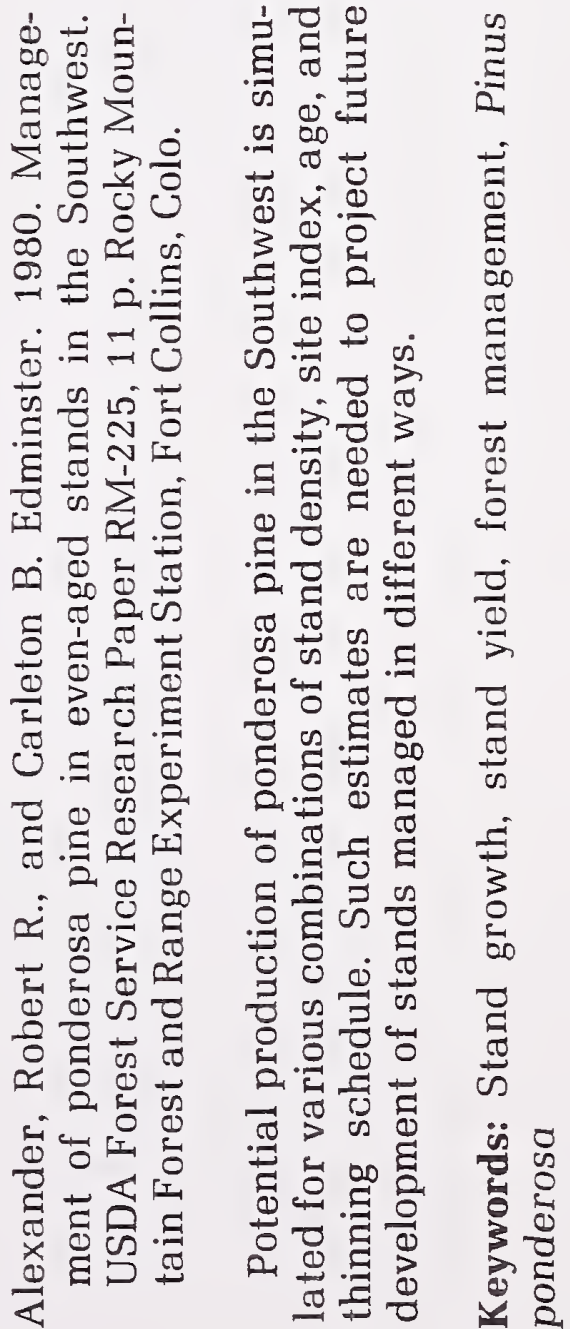




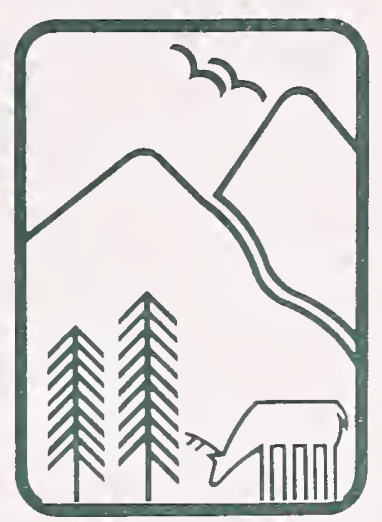

Rocky
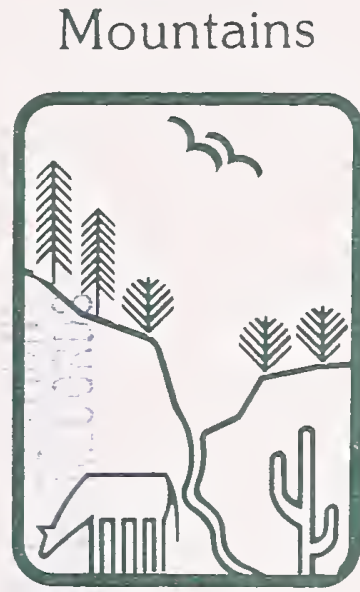

Southwest

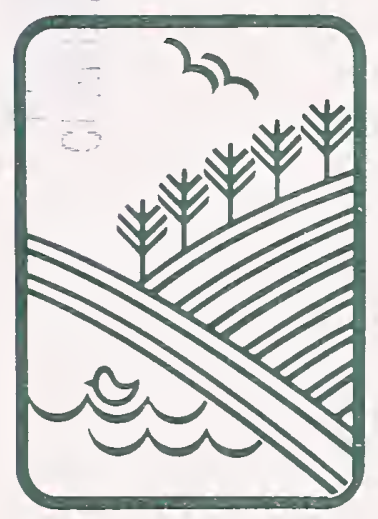

Great

Plains
U.S. Department of Agriculture

Forest Service

\section{Rocky Mountain Forest and Range Experiment Station}

The Rocky Mountain Station is one of eight regional experiment stations, plus the Forest Products Laboratory and the Washington Office Staff, that make up the Forest Service research organization.

\section{RESEARCH FOCUS}

Research programs at the Rocky Mountain Station are coordinated with area universities and with other institutions. Many studies are conducted on a cooperative basis to accelerate solutions to problems involving range, water, wildlife and fish habitat, human and community development, timber, recreation, protection, and multiresource evaluation.

\section{RESEARCH LOCATIONS}

Research Work Units of the Rocky Mountain Station are operated in cooperation with universities in the following cities:

Albuquerque, New Mexico

Bottineau, North Dakota

Flagstaff, Arizona

Fort Collins, Colorado*

Laramie, Wyoming

Lincoln, Nebraska

Lubbock, Texas

Rapid City, South Dakota

Tempe, Arizona

*Station Headquarters: 240 W. Prospect St., Fort Collins, CO 80526 